\title{
Investigation of Employability Perceptions of Sports Science Students
}

\author{
Nuh Osman Y1ld1z (Corresponding author) \\ Bolu Abant İzzet Baysal University, Bolu, Turkey \\ E-mail: nuhosmanyildiz@gmail.com \\ Zülbiye Kaçay \\ Çanakkale Onsekiz Mart University, Çanakkale, Turkey \\ E-mail: zzkacay@gmail.com
}

Güçlü Özen

Izmir Demokrasi University, Izmir, Turkey

E-mail: guclu1234@yahoo.com

Received: November 5, 2021 Accepted: December 3, 2021

Published: December 31, 2021

doi:10.5296/jei.v7i3.19272 URL: https://doi.org/10.5296/jei.v7i3.19272

\begin{abstract}
This study, which was conducted to examine the employability perceptions of students studying in the field of sports sciences in terms of gender, department, type of university, work in the field of diploma and level of foreign language knowledge, was designed according to correlational survey and causal comparison methods. In determining the sample of the study, accessible sampling method, which is one of the non-random sampling methods, was used. The sample in question consists of a total of 206 participants, 99 females (48.1\%) and 107 males (51.9\%). As a measurement tool the "Employability Perception Scale" (IEAS) developed by Rothwell et al. (2008) and adapted into Turkish by Karlı (2016), was used in the study. According to the results of the analysis, a significant difference was determined in terms of gender variable in the University Prestige sub-dimension $(p<0.05)$. No significant difference was determined in terms of other sub-dimensions and variables. As a result, it is possible to state that the employability perception of the students studying in the field of
\end{abstract}


sports sciences is high, that the female participants perceive their university as more prestigious than the male participants, and this contributes positively to their belief that they can be employed in this situation.

Keywords: University prestige, Confidence in the field of study, Self-confidence, Personal development

\section{Introduction}

Advances in science and technology have increased competition for organizations (Soyer et al., 2017), and organizations have had to pay attention to the presence of well-equipped employees in order to cope with the increasing quality and quantity (Kaçay, Güngör, Yenel, \& Soyer, 2020). It can be stated that this situation adds more importance to the competence of university students, who are seen as the future of society, in terms of employability after graduation. The concept of employability, which is defined as the belief of an individual to continue their current job or to be able to work in a desired job (Rothwell \& Arnold, 2007), has become a subject of serious interest both in European Union countries (Ayala \& Garcia, 2021) and in countries such as the United Kingdom. Since the 1990s, substantial resources have been devoted to efforts to develop graduate employability skills at UK universities (Mason et al., 2009; Rothwell et al., 2009). The concept of employability gains importance in the Republic of Turkey also as the number of both state and foundation universities increases day by day and the number of students studying at universities increases accordingly. As in every field, the number of students and graduates trained in universities in the fields of sports sciences is higher than the workforce demanded in the business world (Yıldı \& Çiftçi, 2021; Çeyiz, Erbil, \& Yilmazoğlu, 2021). It is thought that this situation will create a difference in students' perceptions of the concept of employability. In this context, the aim of the study was to examine the employability perceptions of university students studying in the field of sports sciences in terms of gender, department, type of university, working in the field of diploma and level of foreign language knowledge.

\section{Method}

\subsection{Research Method}

This study, conducted to examine the employability perceptions of students studying in the field of sports sciences in terms of gender, department, type of university, field of diploma and level of foreign language knowledge, was designed according to correlational survey and causal comparison methods.

\subsection{Study Group}

In determining the sample of the study, accessible sampling method, which is one of the non-random sampling methods, was used. The sample in question comprides of a total of 206 participants, 99 females (48.1\%) and 107 males (51.9\%).

\subsection{Data Collection Tool}

The "Employability Perception Scale" (IEAS), developed by Rothwell et al. (2008) and 


\section{Macrothink

adapted into Turkish by Karlı (2016), was used. The scale consists of three sub-dimensions, namely University Prestige, Confidence in the Field of Study and Self-Confidence, and 10 items. The scale is a five-point Likert type and is scored as 1 strongly disagree, 2 disagree, 3 undecided, 4 agree and 5 completely agree. Within the scope of this study, the internal consistency coefficients of the scale vary between $\alpha=.76$ and .91 . In addition, confirmatory factor analysis was performed to test the validity and reliability of the measurement tool in this study. The results of the analysis are given below.

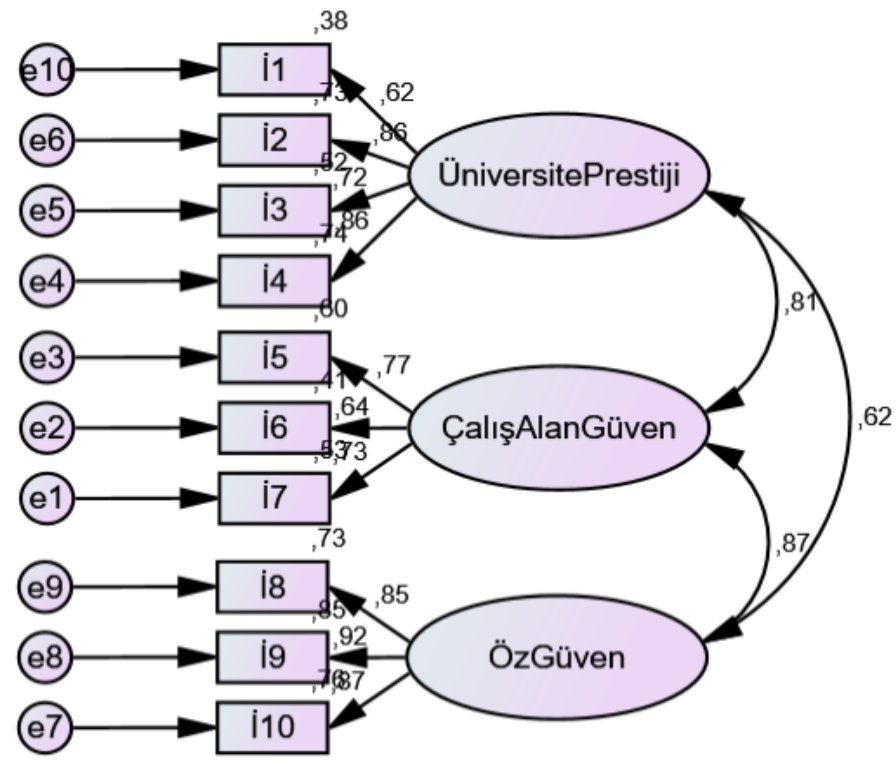

CMIN=57,792; DF=32; p=,003; CMIN/DF=1,806, RMSEA=,063; CFI=,979; TLI=,971

After the Confirmatory Factor Analysis, when the values accepted in the literature regarding the scale (Gürbüz, 2019, Hu and Bentler, 1999) were examined; $\chi^{2}(57,792)$, df (32), $\chi^{2} / \mathrm{df}$ (1.806), CFI (.979), TLI (.971), SRMR (.039) and RMSEA (.063) fit index values were determined as in the criterion value range (Tabachnick et al., 2007, Çokluk, Şekercioğlu, \& Büyüköztürk, 2016; Gürbüz, 2019). In addition, CR and AVE values were calculated. After the analysis, it was concluded that the CR values differed between 0.76 and $0.91(\mathrm{CR}>0.70)$, and the AVE values between 0.52 and 0.80 (AVE > 0.50). When the values were examined in line with the relevant literature, it was determined that the said values were within the criterion value range (Gürbüz, 2019). In line with the CFA results of the scale used in the study, the structure of the "Employability Perception Scale" with 3 sub-dimensions and 10 items was reconfirmed.

\subsection{Analysis of Data}

First, descriptive statistics were made on the obtained data. Normality test was used to determine whether the data were normally distributed and parametric tests were performed 
after determining that the data were normally distributed. During the analysis of the data, t-Test in Unrelated Samples was used for the analysis of gender, university type, and study variables in the field of diploma, and One-Way Analysis of Variance (ANOVA) analyzes were used for the level of department and language proficiency.

\section{Results}

In this section, the data on the study of students' employability perceptions in terms of gender, department, type of university, working in the field of diploma and level of foreign language knowledge were analyzed. Findings related to the analysis are reported below.

Table 1. Demographic information on participants

\begin{tabular}{|c|c|c|c|}
\hline Demographic Variable & Subgroup & Frequency & Percent (\%) \\
\hline \multirow{3}{*}{ Gender } & Female & 99 & $\% 48.1$ \\
\hline & Male & 107 & $\% 51.9$ \\
\hline & Total & 206 & $\% 100$ \\
\hline Age & $18-24$ & $206(\bar{x}=21.31)$ & $\% 100$ \\
\hline \multirow{5}{*}{ Department } & Coaching & 65 & $\% 31.6$ \\
\hline & Physical Education and Sports Teaching & 51 & $\% 24.8$ \\
\hline & Sports Management & 71 & $\% 34.5$ \\
\hline & Recreation & 19 & $\% 9.2$ \\
\hline & Total & 206 & $\% 100$ \\
\hline \multirow{3}{*}{ University Type } & State & 110 & $\% 53.4$ \\
\hline & Private (Foundation) & 96 & $\% 46.6$ \\
\hline & Total & 206 & $\% 100$ \\
\hline \multirow{3}{*}{ Working in the Diploma Field } & Employee & 70 & $\% 34.0$ \\
\hline & Not working & 136 & $\% 66.0$ \\
\hline & Total & 206 & $\% 100$ \\
\hline \multirow{4}{*}{ Foreign Language Level } & $\mathrm{Bad}$ & 86 & $\% 41.7$ \\
\hline & Middle & 99 & $\% 48.1$ \\
\hline & Good & 21 & $\% 10.2$ \\
\hline & Total & 206 & $\% 100$ \\
\hline
\end{tabular}




\section{Macrothink

Table 1 showed that 99 (48.1\%) of the participants were female, 107 (51.9\%) were male, their average age was 21.31, the age range was between 18 and 24, 65 of them had Coaching Education, 51 of them were Physical Education. and Sports Teaching, 71 of them Sports Management, 19 of them studied at Recreation departments, 110 of them continued their education at state universities, 962 of them continued their education at private (foundation) universities, 70 of them worked in a job related to the diploma field, 136 of them with diploma field. It is possible to say that 86 of them have a bad level of foreign language knowledge, 99 of them have a medium level of knowledge, and 21 of them have a good level of foreign language knowledge.

Table 2. Findings related to the comparison of the Perception of Employability Scale and its sub-dimensions in terms of gender variable

\begin{tabular}{|c|c|c|c|c|c|c|c|}
\hline Dimension & Gender & $\mathbf{n}$ & Avr. & SS & SD & $\mathbf{t}$ & $\mathbf{P}$ \\
\hline \multirow[t]{2}{*}{ University Prestige } & Female & 99 & 3.17 & 0.77 & \multirow[t]{2}{*}{204} & \multirow[t]{2}{*}{2.806} & \multirow[t]{2}{*}{0.005} \\
\hline & Male & 107 & 2.82 & 0.99 & & & \\
\hline \multirow[t]{2}{*}{ Confidence in the Workspace } & Female & 99 & 3.38 & 0.81 & \multirow[t]{2}{*}{204} & \multirow[t]{2}{*}{0.663} & \multirow[t]{2}{*}{0.508} \\
\hline & Male & 107 & 3.29 & 1.05 & & & \\
\hline \multirow[t]{2}{*}{ Confidence } & Female & 99 & 3.84 & 0.97 & \multirow[t]{2}{*}{204} & \multirow[t]{2}{*}{-0.416} & \multirow[t]{2}{*}{0.678} \\
\hline & Male & 107 & 3.90 & 1.12 & & & \\
\hline \multirow{2}{*}{ Employability } & Female & 99 & 3.43 & 0.74 & \multirow[t]{2}{*}{204} & \multirow[t]{2}{*}{1.269} & \multirow[t]{2}{*}{0.206} \\
\hline & Male & 107 & 3.28 & 0.92 & & & \\
\hline
\end{tabular}

According to Table 2 a significant difference was determined in the University Prestige sub-dimension in terms of gender $\left(\mathrm{t}_{(204)}=2.806\right.$ and $\left.\mathrm{p}<0.05\right)$. It was etermined that female students $(3.17 \pm 0.77)$ had a higher perception level of the prestige of their universities than male students $(2.82 \pm 0.99)$.

No significant difference was determined in terms of gender variable in the sub-dimension of Confidence in the Study Area $\left(\mathrm{t}_{(204)}=0.663\right.$ and $\left.\mathrm{p}>0.05\right)$.

No significant difference was determined in terms of gender variable in the Self-Confidence sub-dimension $\left(\mathrm{t}_{(204)}=-0.416\right.$ and $\left.\mathrm{p}>0.05\right)$.

No significant difference was determined in terms of gender variable in the total of Employability Perception Scale $\left(\mathrm{t}_{(204)}=1.269\right.$ and $\left.\mathrm{p}>0.05\right)$. 


\section{Macrothink}

Table 3. Findings related to the comparison of Employability Perception Scale and its sub-dimensions in terms of university type variable

\begin{tabular}{|c|c|c|c|c|c|c|c|}
\hline Dimension & University Type & $\mathbf{n}$ & Avr. & SS & SD & $\mathbf{t}$ & $\mathbf{P}$ \\
\hline \multirow{2}{*}{ University Prestige } & State & 110 & 3.10 & 0.89 & \multirow{2}{*}{204} & \multirow{2}{*}{1.916} & \multirow{2}{*}{0.057} \\
\hline & Private & 96 & 2.85 & 0.92 & & & \\
\hline \multirow{2}{*}{ Confidence in the Workspace } & State & 110 & 3.29 & 0.96 & \multirow{2}{*}{204} & \multirow{2}{*}{-0.714} & \multirow{2}{*}{0.476} \\
\hline & Private & 96 & 3.38 & 0.92 & & & \\
\hline \multirow{2}{*}{ Confidence } & State & 110 & 3.84 & 1.05 & \multirow{2}{*}{204} & \multirow{2}{*}{-0.507} & \multirow{2}{*}{0.612} \\
\hline & Private & 96 & 3.92 & 1.04 & & & \\
\hline \multirow{2}{*}{ Employability } & State & 110 & 3.38 & 0.87 & \multirow{2}{*}{204} & \multirow{2}{*}{0.394} & \multirow{2}{*}{0.694} \\
\hline & Private & 96 & 3.33 & 0.80 & & & \\
\hline
\end{tabular}

When Table 3 was examined, it can be said that no significant difference was determined in terms of university type variable in the University Prestige sub-dimension $\left(\mathrm{t}_{(204)}=1.916\right.$ and $\mathrm{p}>0.05)$.

No significant difference was determined in the sub-dimension of Confidence in the Study Area in terms of the type of university $\left(\mathrm{t}_{(204)}=-0.714\right.$ and $\left.\mathrm{p}>0.05\right)$.

In the Self-Confidence sub-dimension, no significant difference was determined in terms of the university type variable $\left(\mathrm{t}_{(204)}=-0.507\right.$ and $\left.\mathrm{p}>0.05\right)$.

No significant difference was found in the total of Employability Perception Scale in terms of university type variable $\left(\mathrm{t}_{(204)}=0.394\right.$ and $\left.\mathrm{p}>0.05\right)$. 


\section{Macrothink Minstitute"'}

Table 4. Findings related to the comparison of Employability Perception Scale and its sub-dimensions in terms of working variable in the field of diploma

\begin{tabular}{|c|c|c|c|c|c|c|c|}
\hline Dimension & Working in the field of diploma & $\mathbf{n}$ & Avr. & SS & SD & $\mathbf{t}$ & $\mathbf{P}$ \\
\hline \multirow{2}{*}{ University Prestige } & Employee & 70 & 3.05 & 0.95 & \multirow{2}{*}{204} & \multirow{2}{*}{0.726} & \multirow{2}{*}{0.469} \\
\hline & Not working & 136 & 2.95 & 0.89 & & & \\
\hline \multirow{2}{*}{ Confidence in the Working Field } & Employee & 70 & 3.46 & 0.98 & \multirow{2}{*}{204} & \multirow{2}{*}{1.437} & \multirow{2}{*}{0.152} \\
\hline & Not working & 136 & 3.26 & 0.92 & & & \\
\hline \multirow{2}{*}{ Confidence } & Employee & 70 & 3.94 & 1.09 & \multirow{2}{*}{204} & \multirow{2}{*}{0.612} & \multirow{2}{*}{0.541} \\
\hline & Not working & 136 & 3.84 & 1.03 & & & \\
\hline \multirow{2}{*}{ Employability } & Employee & 70 & 3.44 & 0.90 & \multirow{2}{*}{204} & \multirow{2}{*}{1.030} & \multirow{2}{*}{0.304} \\
\hline & Not working & 136 & 3.31 & 0.80 & & & \\
\hline
\end{tabular}

When Table 4 was examined, no significant difference was determined in the University Prestige sub-dimension in terms of the variable of working in the field of diploma $\left(\mathrm{t}_{(204)}=\right.$ 0.726 and $\mathrm{p}>0.05)$.

In the sub-dimension of Confidence in the Field of Study, no significant difference was determined in terms of the variable of working in the field of diploma $\left(\mathrm{t}_{(204)}=1.437\right.$ and $\mathrm{p}>$ $0.05)$.

In the Self-Confidence sub-dimension, no significant difference was determined in terms of the variable of working in the field of diploma $\left(\mathrm{t}_{(204)}=-0.612\right.$ and $\left.\mathrm{p}>0.05\right)$.

No significant difference was determined in the total of the Employability Perception Scale in terms of the variable of employment in the field of diploma $\left(t_{(204)}=1.030\right.$ and $\left.p>0.05\right)$. 


\section{Macrothink}

Journal of Educational Issues

ISSN 2377-2263

2021, Vol. 7, No. 3, Special Issue

Table 5. Findings on the Comparison of the Perception of Employability Scale and its sub-dimensions in terms of the department variable

\begin{tabular}{|c|c|c|c|c|c|c|}
\hline Dimension & Department & $\mathbf{N}$ & Avr. & SS & $\mathbf{F}$ & $\mathbf{p}$ \\
\hline \multirow{4}{*}{ University Prestige } & Coaching & 65 & 2.97 & 0.92 & \multirow{4}{*}{1.641} & \multirow{4}{*}{0.181} \\
\hline & PES & 51 & 3.00 & 0.91 & & \\
\hline & SM & 71 & 3.09 & 0.85 & & \\
\hline & Recreation & 19 & 2.57 & 1.02 & & \\
\hline \multirow{4}{*}{ Confidence in the Working field } & Coaching & 65 & 3.29 & 1.00 & \multirow{4}{*}{1.310} & \multirow{4}{*}{0.272} \\
\hline & PES & 51 & 3.49 & 0.89 & & \\
\hline & SM & 71 & 3.35 & 0.87 & & \\
\hline & Recreation & 19 & 3.00 & 1.09 & & \\
\hline \multirow{4}{*}{ Confidence } & Coaching & 65 & 3.81 & 1.15 & \multirow{4}{*}{0.388} & \multirow{4}{*}{0.762} \\
\hline & PES & 51 & 3.97 & 0.84 & & \\
\hline & SM & 71 & 3.91 & 1.01 & & \\
\hline & Recreation & 19 & 3.71 & 1.36 & & \\
\hline \multirow{4}{*}{ Employability Perception } & Coaching & 65 & 3.32 & 0.92 & \multirow{4}{*}{1.198} & \multirow{4}{*}{0.312} \\
\hline & PES & 51 & 3.44 & 0.70 & & \\
\hline & SM & 71 & 3.41 & 0.80 & & \\
\hline & Recreation & 19 & 3.04 & 0.98 & & \\
\hline
\end{tabular}

Note. PES: Physical Education and Sports Teaching; SM: Sports Management.

According to Table 5, no significant difference was determined in the University Prestige sub-dimension in terms of department variable $F(3,202)=1,641, p>0.05)$.

In the sub-dimension of Confidence in the Study Area, no significant difference was determined in terms of the department variable $F(3,202)=1,310, p>0.05)$.

In the Self-Confidence sub-dimension, no significant difference was determined in terms of the department variable $F(3,202)=0.388, p>0.05)$.

No significant difference was determined in the total of Employability Perception Scale in terms of department variable $F(3,202)=1,198, p>0.05)$. 


\section{Macrothink}

Table 6. Findings related to the comparison of Employability Perception Scale and its sub-dimensions in terms of foreign language knowledge variable

\begin{tabular}{|c|c|c|c|c|c|c|}
\hline Dimension & Foreign Language Knowledge & $\mathbf{n}$ & Ort. & SS & $\mathbf{F}$ & $\mathbf{p}$ \\
\hline \multirow{3}{*}{ University Prestige } & $\mathrm{Bad}$ & 86 & 2.88 & 0.91 & \multirow{3}{*}{0.876} & \multirow{3}{*}{0.418} \\
\hline & Medium & 99 & 3.06 & 0.90 & & \\
\hline & Good & 21 & 3.05 & 0.97 & & \\
\hline \multirow{3}{*}{ Confidence in Work Field } & $\mathrm{Bad}$ & 86 & 3.25 & 0.92 & \multirow{3}{*}{0.524} & \multirow{3}{*}{0.593} \\
\hline & Medium & 99 & 3.39 & 0.96 & & \\
\hline & Good & 21 & 3.36 & 0.95 & & \\
\hline \multirow{3}{*}{ Confidence } & $\mathrm{Bad}$ & 86 & 3.68 & 1.16 & \multirow{3}{*}{2.463} & \multirow{3}{*}{0.088} \\
\hline & Medium & 99 & 4.01 & 0.93 & & \\
\hline & Good & 21 & 4.04 & 1.01 & & \\
\hline \multirow{3}{*}{ Employability Perception } & $\mathrm{Bad}$ & 86 & 3.23 & 0.84 & \multirow{3}{*}{1.527} & \multirow{3}{*}{0.220} \\
\hline & Medium & 99 & 3.44 & 0.82 & & \\
\hline & Good & 21 & 3.44 & 0.84 & & \\
\hline
\end{tabular}

When Table 6 was examined, no significant difference was determined in the University Prestige sub-dimension in terms of foreign language knowledge $\left.F_{(2.203)}=0.876, p>0.05\right)$.

In the sub-dimension of Confidence in the Study Area, no significant difference was determined in terms of foreign language knowledge $\left.F_{(2.203)}=0.524, p>0.05\right)$.

In the Self-Confidence sub-dimension, no significant difference was determined in terms of foreign language knowledge $\left.\mathrm{F}_{(2.203)}=2.463, \mathrm{p}>0.05\right)$.

No significant difference was determined in the total of Employability Perception Scale in terms of foreign language knowledge variable $\left.\mathrm{F}_{(2.203)}=1.527, \mathrm{p}>0.05\right)$.

\section{Discussion}

Perception of employability and its sub-dimensions were examined in terms of gender variable, while a significant difference was determined in the sub-dimension of university prestige, no significant difference was determined in the sub-dimension of Employability, Confidence in the Workplace and Self-Confidence. When the studies on employability and gender are examined, there are studies that found a difference in favor of male participants (Vargas et al., 2018) and found a difference in favor of female participants (Rothwell et al., 2009). In addition to these studies, in the studies conducted by Karl1 (2016), Jackson and Wilton (2017), and Taze and Karayol (2020), the perception of employability was examined in terms of gender variable, and no significant difference was determined in the total score 
and sub-dimensions of the scale. The results of these studies are in parallel with the results of this study. The result found in this study is thought to be due to the self-confidence of all individuals, regardless of men and women, that they can work in any field, including the sports sector. Because in recent years, universities employing their students as part-time in their own businesses, especially in businesses that require expertise such as sports sciences, supports this situation. In this way, students have the opportunity to be employed even during their education. It can be said that the difference in favor of women in terms of gender variable in the sub-dimension of university prestige is due to the fact that female participants think that the prestige of their universities will be effective in their employment opportunities, and that the perception of prestige attributed by the society in their business life will be important because of the market they are in.

No significant difference was determined in the sub-dimensions of employability perception and university prestige, trust in the field of study and self-confidence in terms of the type of university that was categorized as foundation and state. When the relevant literature regarding this result was examined, no study could be found on the subject. It is thought that this result will shed light on similar studies to be made in the future. The source of the result is thought to be the provision of education equality in state and foundation universities, since state and foundation universities continue their education activities with common curricula today.

Employability, university prestige, trust in the field of study, self-confidence were examined in terms of working in the field of diploma variable and no significant difference was determined. When the studies on the perception of work experience and employability are examined, there are studies that have determined that work experience is effective or not in the perception of employability (Karl1, 2016). The studies conducted by Rothwell (2009) and Kamaliah (2018), on the other hand, obtained a result consistent with the result determined in this study and did not detect a significant difference in the employability perceptions of individuals who had a previous work experience. The fact that sports science students believe that they can be employed because of the increase in the number of businesses opened in the private sector and the regular increase in the quota for appointment in the public sector in recent years is thought to be the source of the result of the study.

Employability, university prestige, confidence in the field of study, self-confidence were examined in terms of sports science departments variable and no significant difference was determined. In a study conducted by Yildiz et al. (2008), the perceptions of sports science students that they can be employed were questioned and it was observed that the average scores obtained were very close to each other and no significant difference was obtained. In another study conducted by Atalay (2020), the employability perceptions of sports science students were examined in terms of the department variable and no significant difference was determined. The results of the studies in the literature support the results of this study. Through the certification programs for the departments in the field of sports sciences, all departments have the opportunity to work in almost each other's fields. Individuals can become coaches with the coaching training courses opened by sports federations. Individuals who have been educated in the field of sports sciences can work as physical education teachers by taking formation training after undergraduate education. Therefore, all sports 
science students can work in different sports science fields. It is possible to say that this situation eliminates the perception of departmental difference in students. It is thought that the reason for this result is due to this situation.

In terms of foreign language variable, no significant difference was determined in all dimensions. In a study by Karlı (2016), the employability perceptions of sports science students in terms of foreign language variable were examined and no significant difference was determined. The result of this study is in agreement with the result of this study.

The curricula of all universities providing education in the field of sports sciences have been made common in recent years. Within these curricula, foreign language education is compulsory in all universities. It is thought that this situation is effective in equalizing the level of foreign language knowledge among students. Therefore, it is possible to say that the aforementioned result may be due to the aforementioned issue.

\section{Conclusion}

As a result, it is possible to state that students studying in the field of sports sciences have high employability perceptions, that female participants perceive their universities as more prestigious than male participants, and this contributes positively to their belief that they can be employed in this situation. In addition, it is thought that this study will shed light on the decision makers and curriculum developers of the institutions and organizations that provide education in the field of sports sciences.

\section{References}

Atalay, A. (2020). İstihdam Edilebilir Miyim? Beden Eğitimi ve Spor Yüksekokulu Öğrencilerinin İstihdam Edilebilme Algilari: Ardahan Üniversitesi Örneği. Spor ve Performans Araştırmaları Dergisi, 11(3), 245-257. https://doi.org/10.17155/omuspd.672280

Ayala Calvo, J. C., \& Manzano García, G. (2021). The influence of psychological capital on graduates' perception of employability: The mediating role of employability skills. Higher Education Research \& Development, 40(2), 293-308. https://doi.org/10.1080/07294360.2020. 1738350

Çeyiz, S., Erbil, S., \& Yilmazoğlu, H. C. (2021). Spor Bilimleri Alanında Öğrenci Olmak: Bir Metafor Çalışması. OPUS Uluslararası Toplum Araştırmaları Dergisi, 17(38), 5210-5227. https://doi.org/10.26466/opus.841871

Çokluk, Ö., Şekercioğlu, G., \& Büyüköztürk, Ş. (2012). Sosyal bilimler için çok değişkenli istatistik: SPSS ve LISREL uygulamaları (Vol. 2). Ankara: Pegem Akademi.

Gürbüz, S. (2019). AMOS ile yapısal eşitlik modellemesi. Ankara: Seçkin Yayıncılık.

Hu, L. T., \& Bentler, P. M. (1999). Cutoff criteria for fit indexes in covariance structure analysis: Conventional criteria versus new alternatives. Structural Equation Modeling: A Multidisciplinary Journal, 6(1), 1-55. https://doi.org/10.1080/10705519909540118

Jackson, D., \& Wilton, N. (2017). Perceived employability among undergraduates and the 
importance of career self-management, work experience and individual characteristics. Higher Education Research \& Development, 36(4), 747-762. https://doi.org/10.1080/ 07294360.2016 .1229270

Kaçay, Z., Güngör, N. B., Yenel, F., \& Soyer, F. (2020). The Effect of Work Engagement and Mindfulness on Organizational Behavior. Journal of Educational Issues, 6(2), 478-492. https://doi.org/10.5296/jei.v6i2.17975

Kamaliah, S., Roslan, S., Bakar, A. R., \& Ghiami, Z. (2018). The effect of supervised work experience on the acquisition of employability skills among Malaysian students. Higher Education, Skills and Work-Based Learning, 8(4), 354-364. https://doi.org/10.1108/ heswbl-05-2016-0028

Karli, U. (2016). Adaptation and Validation of Self-Perceived Employability Scale: An Analysis of Sports Department Students and Graduates. Educational Research and Reviews, 11(8), 848-859. https://doi.org/10.5897/ERR2016.2712

Mason, G., Williams, G., \& Cranmer, S. (2009). Employability skills initiatives in higher education: What effects do they have on graduate labour market outcomes? Education Economics, 17(1), 1-30. https://doi.org/10.1080/09645290802028315

Rothwell, A., \& Arnold, J. (2007). Self-perceived Employability: Development and Validation of a Scale. Personnel Review, 36(1), 23-41. https://doi.org/10.1108/00483480710 716704

Rothwell, A., Herbert, I., \& Rothwell, F. (2008). Self-perceived employability: Construction and initial validation of a scale for university students. Journal of Vocational Behavior, 73(1), 1-12. https://doi.org/10.1016/j.jvb.2007.12.001

Rothwell, A., Jewell, S., \& Hardie, M. (2009). Self-perceived employability: Investigating the responses of post-graduate students. Journal of Vocational Behavior, 75(2), 152-161. https://doi.org/10.1016/j.jvb.2009.05.002

Soyer, F., Demirel, M., Kacay, Z., Ayhan, C., \& Demirel, D. H. (2017). Examination of the Opinions of University Students on the Meaning of Leisure Time and the Lesson Study Approaches. Examination of Control Focus and Psychological Endurance Levels by Various Variables According to Sports Activity, 18. https://doi.org/10.5782/kjhss.2017.5.18.31

Tabachnick, B. G., Fidell, L. S., \& Ullman, J. B. (2007). Using multivariate statistics (Vol. 5, pp. 481-498). Boston, MA: Pearson.

Taze, M., \& Karayol, M. (2020). Investigation of Entrepreneurship Levels and Employability Perception of Undergraduate Students Studying Sports Sciences. International Education Studies, 13(5), 35-43. https://doi.org/10.5539/ies.v13n5p35

Vargas, R., Sánchez-Queija, M. I., Rothwell, A., \& Parra, A. (2018). Self-perceived employability in Spain. Education+ Training, 60(3), 226-237. https://doi.org/10.1108/ET-032017-0037 

ISSN 2377-2263

Yıldız, N. O., \& Çiftçi S. (2021) Spor işletmelerinde hedef belirleme süreci: Dalış okulları örneği. Ankara, Gazi Kitabevi.

Yildiz, S. M. (2008). Beden eğitimi ve spor öğretimi veren yükseköğretim kurumlari ve istihdam durumlari. Kastamonu Ĕ̈itim Dergisi, 16(2), 651-656.

\section{Copyright Disclaimer}

Copyright for this article is retained by the author(s), with first publication rights granted to the journal.

This is an open-access article distributed under the terms and conditions of the Creative Commons Attribution license (http://creativecommons.org/licenses/by/3.0/). 